\title{
THE MYTH OF THE WAR OF THE SEVEN AND PAUSANIAS' EDUCATIONAL TOPOGRAPHY ${ }^{*}$
}

Andrej Yu. MOZHAJSKY

The article examines the monuments of Thebes mentioned by Pausanias and related to the story of Seven against Thebes. It is claimed that these monuments were a part of the local educational practice, which reflected the Theban mythical history and fostered patriotism. Most of the monuments were located near the gates of the Kadmeia (at a distance of up to $260 \mathrm{~m}$ ) and formed a close circle of monuments. In some cases, the monuments formed a far circle (at a distance of 300 to 500-960 m from the gates). The first of the monuments considered is the monument associated with Amphiaraos. Regarding the place where the earth swallowed Amphiaraos, there exist two traditions, namely the "Theban" and the "Tanagrian" ones. It is hypothesized that the "Tanagrian" tradition was adapted by the residents of Oropos and, thus, reflected in Euripides' tragedy The Phoenician Women. The educational topography of Pausanias shows that the "Theban" version is consistent with the text of Aischylos' tragedy Seven against Thebes, while the "Tanagrian" version is consistent with the text of The Phoenician Women by Euripides. The location of the tombs of Melanippos and Tydeus near the Proitides gates also corresponds to the tradition captured by Aischylos, which presumably reflects the local, or "Theban", version of the myth. Through Pausanias' educational topography, the connection of the figure of Kapaneus with the Elektrai Gates and the walls of Thebes is emphasized, which is confirmed by the evidence of material culture. As a possible grave of Oidipous' children, the largest of the chamber

* The study was carried out with a grant from the Russian Science Foundation (project No. 18-78-10001).

HYPOTHEKAI

2020. Вып. 4. С. 171-206

УДК 37.01
HYPOTHEKAI

2020. Issue 4. P. 171-206

DOI: $\underline{10.32880 / 2587-7127-2019-4-4-171-206}$ 
tombs on the hill of Megalo Kastelli is considered. A large number of monuments associated with the story of Seven against Thebes symbolized military valour and glorified Thebes in their victory over the Argives. Some of the monuments possess ambiguous symbolism, among which are the tomb of Menoikeus and the place of the duel between the sons of Oidipous. The article is equipped with a map reconstructing the probable location of the monuments, including various versions of their localization, as well as illustrations with the images on the objects of material culture associated with the War of the Seven.

\section{INTRODUCTION \\ THE SIGNIFICANCE OF PAUSANIAS’ WORK FOR THE LOCALIZATION OF ANCIENT MONUMENTS ${ }^{1}$}

Pausanias, an author of the 2nd century BC, in his Book IX of Descriptions of Greece wrote about the monuments of Boiotia, including the history and monuments of Thebes (Paus. 9.5-18). Its description includes both the legendary history of Thebes and the narrative which rests on a more solid basis of the historical time. Pausanias examines sanctuaries and other monuments of different epochs ${ }^{2}$. Our study has the following objec-

${ }^{1}$ This article was presented in English as a paper during "Myth and Politics from Antiquity to the Present Time" International Summer Seminar series hosted at the Department of Classics, Ancient History \& Egyptology at Swansea University on 15th June 2020. I express my deep gratitude to V.K. Pichugina for her valuable comments made during the work on the article.

${ }^{2}$ There is numerous historiography regarding the narration of Pausanias, including texts where Thebes are mentioned. We will cite only some classical works. Though not all of them were quoted in this article, they are important from the point of view of the overall picture. First of all, the following translations and commentaries should be mentioned: Frazer (1898) (Boiotia and Thebes are analyzed by Frazer in Volume V. Of the modern commentaries, a commented translation of Pausanias' works into Italian, published in 1982-2017 by the publishing house Fondazione Lorenzo Valla-Arnoldo Mondadori, was widely known (for us, Book IX Boiotia: Moggi, Osanna (2010) is of major interest). Very valuable comments, especially from the archaeological and topographical points of view, are commentaries Papakhatzes (1981). In addition, one should pay attention to some classical review articles on Pausanias, including his 
tives: to consider those of Theban monuments that Pausanias describes and that are directly related to the education of a warrior and associated with the myth of Seven against Thebes; to define, as far as possible, their location, time of construction, and historical and pedagogical significance.

To what extent can Pausanias' descriptions be trusted? Researchers have interpreted his work differently. In the dissertation on Pausanias in Athens, Vanessa Champion-Smith distinguishes two groups of authors: the authors who trusted Pausanias' texts, and the authors who treated Pausanias' work hypercritically ${ }^{3}$. Starting from the end of the 19th century, a large group of researchers trusted Pausanias observations, especially with regard to the description of the monuments in Athens. Thus, Harrison and Verrall trust Pausanias in general, but note that "we have abundant evidence that Pausanias was an inaccurate observer and a slipshod

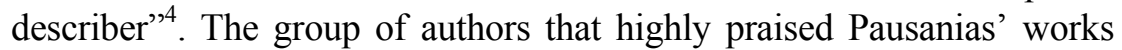
also includes other researchers ${ }^{5}$, among who are Wycherley $^{6}$ and Casson $^{7}$. These researchers placed Pausanias above all the previous ancient authors who worked in this genre. A number of authors had a different point of view on Pausanias' work and did not trust him ${ }^{8}$. Pausanias was criticized, among other things, for the fact that in his work, he had not mentioned many monuments which later became known from other literary sources and archeological data. However, in the twenty-first century it was made clear that a bulk of archaeological data confirms Pausa-

ninth book, which describes Thebes: Regenbogen (1956), Musti (1988), etc. The most significant for us are special works that pay attention to Thebes' topography and archeology and are related to the description of Pausanias: Keramopoullos (1917), Symeonoglou (1985) (especially the chapter "The Description of Thebes by Pausanias" on pages 173-202), as well as Berman (2015).

${ }^{3}$ Champion-Smith (1998). P. 7-10.

${ }^{4}$ Harrison and Verrall (1890). P. 410.

${ }^{5}$ Tarn (1910). P. 216; Henderson (1923). P. 106, 104.

${ }^{6}$ Wycherley (1982). P. 182, 188-189, 191: "Homer Thompson and I have walked the streets of Athens with Pausanias for over half a century, found him a congenial companion in spite of faults and eccentricities, and become constantly more aware of his trustworthiness and unique value as a guide...".

${ }^{7}$ Casson (1974). P. 292-299.

${ }^{8}$ Cp. Wilamowitz-Möellendorff (1883). P. 251, n.2. 
nias' reports, and not mentioning some of those monuments could be explained by the author's intention.

One of the most striking examples of the accuracy of Pausanias' narration and his localization of the monuments is the discovery of the sanctuary of Heracles in Thebes, which was made by Vassilis Aravantinos ${ }^{9}$. This sanctuary was located in full accordance with Pausa-

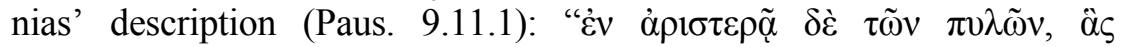

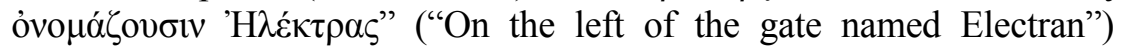
(translated by W.H.S. Jones.). This example is the most indicative for us, since this article deals with the monuments in Thebes.

Thus, we can assume that Pausanias' messages regarding the localization of certain monuments and their descriptions can be trusted. Nevertheless, one should treat Pausanias' reports about dating this or that monument and his interpretation of iconography with a pinch of salt. In this regard, Pausanias' texts are more likely a source of information about what places in Thebes connected the Thebans with their mythical past in the 2nd century AD. In this case, our approach, in some way, corresponds to Sélincourt's approach to one of Herodotos' texts, which the latter heard in Memphis: "This admirable story is hardly likely to be true; but - and this is the thing to remember - it was a popular belief current in the streets of Memphis in the fifth century before Christ, and doubtless for centuries before that, and as such it has its value" $" 10$.

However, using archaeological and topographic data, we will try to establish, where possible, the probable time for the appearance of monuments reflecting the Theban ideology of warrior education, as well as to interpret the literary tradition associated with the mythological past of Thebes and these monuments.

\section{THE ROAD FROM PLATAIAI TO THEBES}

\section{AMPHIARAOS’ ПEPIBO $\Lambda \mathrm{O} \Sigma$}

In his description, Pausanias follows the path from Plataiai to Thebes and in paragraph 4.4., he brings the description to the Asopos river, which in his time still separated the region of Thebes from the re-

${ }^{9}$ About discovering and exploring the sanctuary, see: Aravantinos (2014), Aravantinos (2015a), Aravantinos (2017).

${ }^{10}$ Sélincourt (2001). P. 38. 
gion of Plataiai (Paus. 9.4.4). Further, in paragraphs 5.1-3, Pausanias describes the foundation and early mythological history of Thebes. Then, in paragraphs 5.4-16, the mythological kings of Thebes appear before the reader (Paus. 9.5) ${ }^{11}$. Pausanias goes on to describe the wars of the fifth and fourth centuries $\mathrm{BC}$, in which the Thebans took part, speaks of the destruction of Thebes by Alexander and the further restoration of the city by Kassandros. He then talks about the history of Thebes in Roman times and emphasizes that in his time, "the lower city of Thebes is all deserted today, except the sanctuaries, and the people live on the citadel, which they call Thebes and not Cadmeia" (translated by W. H. S. Jones) (Paus. 9.6-7). Pausanias then describes the area on the Theban side of the Asopos, including Potniai, and the path from it to Thebes, including the possible remains of the ancient sanctuary of Amphiaraos (Paus. 9.8.1$2)^{12}$. In our opinion, this is the first monument in Pausanias' description, which can be associated with the military valour of Thebes, as the local tradition accurately connected this place with the legendary defense of the city during the mythical "Seven against Thebes" campaign. In our 2014 article (see the link above), we tried to localize this place and associate it with the early sanctuary, where the Amphiaraos oracle was located (Hdt. 1.46, 1.49, 1.52) ${ }^{13}$. Pausanias mentions the following: "On the way from Potniae to Thebes there is on the right of the road a small enclosure with pillars in it. Here they think the earth opened to receive Amphiaraus, and they add further that neither do birds sit upon these pillars, nor will a beast, tame or wild, graze on the grass that grows here" (Paus. 9.8.3; translated by W.H.S. Jones). Omitting the analyzed versions of the oracle location, we may assume that the closest place to Thebes is $\pi \varepsilon \rho i \beta o \lambda o \varsigma$, described by Pausanias on the way from Potniai to Thebes. Archaeologists identify ancient Potniai with the settlement of Tachy, which is located on the northern edge of the Parasopia, about two kilometers southwest from the center of modern Thebes ${ }^{14}$. However, Pausanias

${ }^{11}$ For further detail, see Regenbogen's commentary on these paragraphs from Pausanias (1956). P. 1044.

${ }^{12}$ Regarding the versions of the localization of the sanctuary of Amphiaraos, see: Mozhajsky (2014). P. 77-78.

${ }^{13}$ Cf. Renberg (2017). P. 660-676.

${ }^{14}$ Fossey (1988). P. 208; Papadaki (2000); Mozhajsky (2014). P. 78. Also see Lamont's review of Renberg: Lamont (2019). P. 180-181. 
has another tradition about the place where the earth swallowed Amphiaraos. In order to interpret this issue, one should briefly trace the literary tradition of Amphiaraos' connection with Thebes and the location of the oracle, as well as define the place of Pausanias' texts in it.

Homer says that Amphiaraos died in Thebes ( $\dot{\varepsilon} v \Theta \eta \dot{n} \beta \emptyset \mathrm{l})$ (Hom. Od. $15.247)^{15}$. Further, apparently, a version arises, which we conventionally call "Theban", saying that the Theban land swallowed Amphiaraos, thus connecting the oracle with this place. The echoes of this version can be

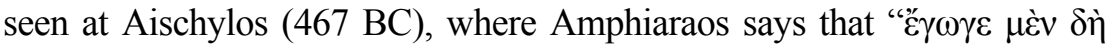

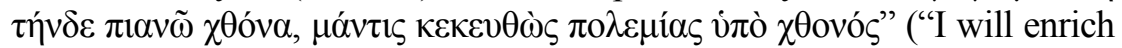
this earth, a seer interred beneath enemy soil") (Sept. 587-588; translated by Herbert Weir Smyth). Moreover, as Renberg notes: "Writing two decades later, Pindar may refer to Amphiaraos issuing oracles in a setting that must be at Thebes, but the ambiguous passage makes no reference to the cult site at which they were issued" $"$. This version is also reflected in Sophocles in the interpretation of Strabo (Strabo 9.1.22; Soph., TrGF IV,

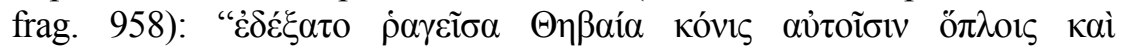

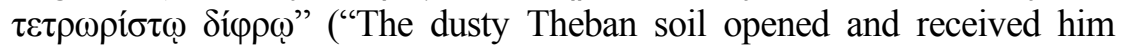
with his armour, and the four-horse chariot") (Strabo 9.1.22; Soph., TrGF IV, frag. 958; translated by W. Falconer). Whether Strabo's description of "an oracle once held in honor" referred to Oropos or Thebes, the quote from Sophocles itself speaks of Thebes as the place of Amphiaraos death. Herodotos also connects the oracle of Amphiaraos with Thebes (Hdt. 1.46, $1.49,1.52,1.92$, especially 8.134 ). Further, the connection of a certain sacred place of Amphiaraos with Thebes is mentioned in the cited text by Pausanias (9.8.3), but Pausanias does not speak of the oracle. It is possibly supplemented by Aristide, who also mentions the sacred site ( $\tau \dot{\varepsilon} \mu \varepsilon v o \varsigma)$ where the earth swallowed Amphiaraos, but does not speak about the oracle and where this place is located (Aristid. Or. 25.60) ${ }^{17}$.

However, Pausanias himself, describing Oropos, conveys another, a

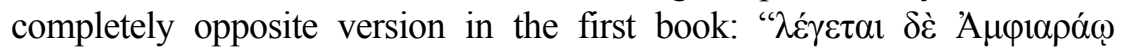

${ }^{15}$ Thus, this tradition is relevant for the eighth century BC, but not earlier than 750 BC; for the dating of Homer's works, see: Osborne (2009), P. 150; bibliography, P. 349-350.

${ }^{6}$ This refers to Pind. Pyth. 8.55-60, see: Renberg (2017). P. 665, n. 15.

${ }^{17}$ In more detail, see: Renberg (2017). P. 666, n. 16. 


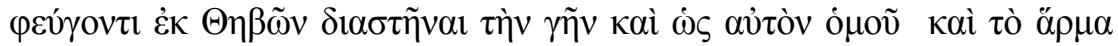

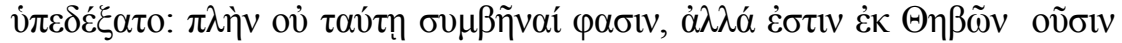

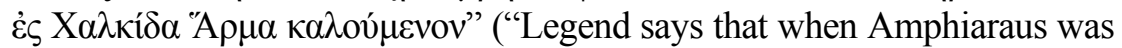
exiled from Thebes the earth opened and swallowed both him and his chariot. Only they say that the incident did not happen here, the place called the Chariot ("A $\rho \mu \alpha-$ A. Mozhajsky) being on the road from Thebes to Chalcis") (Paus. 1.34.2; translated by W.H.S. Jones). For the purpose of our discussion, we can call this version the "Oropian" one, however it was spread not only there, but also in Tanagra, since in another passage of the

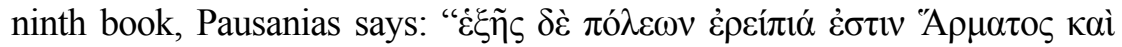

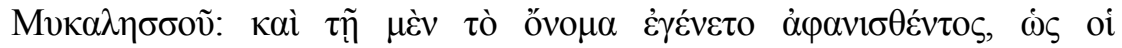

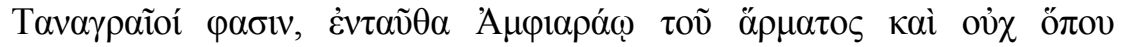
$\lambda \varepsilon ́ \gamma o v \sigma ı v$ oi $\Theta \eta \beta \alpha$ ĩoı" ("Adjoining are the ruins of the cities Harma (Chariot) and Mycalessus. The former got its name, according to the people of Tanagra, because the chariot of Amphiaraus disappeared here, and not where the Thebans say it did") (Paus. 9.19.4; translated by W.H.S. Jones).

Renberg suggests a political version of this message, with which we tend to agree ${ }^{18}$. We will try to explain in more detail the origin of this "Oropian" or, better, "Tanagrian" version. The geographical location of Harma helps to answer this question. According to the localization by Wallace and Fossey, Harma was located at the northern edge of the border between the plains of Thebes and Tanagra ${ }^{19}$, which is a little more than ten kilometers from Tanagra ${ }^{20}$. Thus, Harma could belong to the sphere of Tanagra's influence as it was the largest polis in this area, and it could happen already in the Archaic period ${ }^{21}$. Through Harma and the

${ }^{18}$ Renberg (2017). P. 667, n. 18.

${ }^{19}$ Fossey (1988). P. 85.

${ }^{20}$ The distance from Harma to Thebes is about $16 \mathrm{~km}$, see: Wallace (1979). P. 50.

${ }^{21}$ John Bintliff investigated the process of changing the system of settlements in Boiotia and came to the conclusion that in the sixth century $\mathrm{BC}$, there was a peak of aggressive expansion of the largest centers (to which Tanagra belonged) in relation to the once autonomous smaller settlements, which resulted in the construction of archaic-style walls around all urban settlements. Nevertheless, the incorporation of smaller settlements into the political and economic sphere of dominance of large centers could also take place peaceful- 
story of Amphiaraos' chariot, told by Pausanias, Tanagra could have claimed its antiquity and both religious and political authority in Boiotia. Let us see with the help of archeological data whether this claim was substantiated. How ancient was Harma and can it be associated with the Mycenaean and Geometric periods? Ceramics belonging to the LH III A$\mathrm{B}$ periods were found on the Harma acropolis, which corresponds to a wide time range of approx. 1420-1190 BC. Thus, the material evidence of the maturity and collapse of the Mycenaean civilization was recorded on the Harma acropolis. The same can be said about the Geometric peri$\mathrm{od}^{22}$. As for the literary evidence, Harma is mentioned by Homer in the Catalog of Ships (Il. 2.499). Accordingly, Harma could have claimed to be a place where the earth swallowed Amphiaraos with his chariot, which, in our opinion, the Tanagrians could have taken advantage of. This tradition could become even more firmly established in the period following the weakening of Thebes in $479 \mathrm{BC}$, when the strengthening of Tanagra for some period presumably took place (until $457 \mathrm{BC}$ ) ${ }^{23}$. At the end of the fifth century BC, after the Amphiaraos sanctuary was established in Oropos, this "Tanagrian" version of the earth swallowing up Amphiaraius could have been adapted by the people of Oropos ${ }^{24}$ and Athens as it was politically more beneficial for their oracle than the "Theban" one. In Roman times, when Harma was no longer inhabited, various details of this version made their way into the writings of Strabo (9.2.11), Pausanias (1.34.2; 9.19.4) and Plutarch (Mor. 307A) ${ }^{25}$.

ly. Judging by the figures in Bintliff's articles, beginning from the sixth century BC Harma was supposed to be in Tanagra's sphere of influence, see: Bintliff (1994). P. 225, fig. 26. Bintliff (1999). P. 18-20, fig. 4

${ }^{22}$ Fossey (1988). P. 88. Harma was inhabited up to and including the Hellenistic period.

${ }^{23}$ In $457 \mathrm{BC}$, the Athenians, having defeated the Boiotians at the Battle of Oenophyta, levelled the walls of Tanagra to the ground. On the strengthening of Tanagra during this period and the corresponding bibliography, see: Mozhajsky (2007). P. 77.

${ }^{24}$ The foundation of the oracle of Amphiaraos in Oropos is usually dated between 431 and $414 \mathrm{BC}$, however, Petropoulou suggests a narrower date 420-414 BC, see: Petropoulou (1981).

${ }^{25}$ Renberg also points to another tradition of Amphiaraos presented in the work of Valerius Maximus (8.15, ext. 3), and to a number of other ancient 
Having dealt with the appearance of an alternative version of the site where Amphiaraos was swallowed by the earth, we can focus on the issues associated with Pausanias' $\pi \varepsilon \rho i$ ío ${ }_{0} \varsigma \varsigma$ near Thebes. As I mentioned, in my article (2014), as well as in Renberg's study, there are several options for localizing this place ${ }^{26}$. Keramopoullos' version (immediately to the north of Tachy, in the property of T. Douros-Agatsas) ${ }^{27}$ and Symeonoglou's one (depression in which the church of Agios Nikolaos (site 215 in Symeonoglou's catalog) now stands) seem the most justified $^{28}$. However, it may seem that this localization does not correspond to the well-known passage from The Mythological Library by PseudoApollodoros who writes: "Amphiaraus fled beside the river Ismenus ${ }^{29}$, and before Periclymenus could wound him in the back, Zeus cleft the earth by throwing a thunderbolt, and Amphiaraus vanished with his chariot and his charioteer Baton, or, as some say, Elato" (Ps.-Apollod., Bibl. 3.6.8; translated by Sir. James George Frazer).

This brings up the question: is the localization of Keramopoullos and Symeonoglou not too far from the Ismenos River, which is indicated in the text from Pseudo-Apollodoros? Google Earth Pro offers us the following distances: from Keramopoullos' site $^{30}$, it is approx. $650 \mathrm{~m}$ to the Ismenos River on the straight, and from Symeonoglou's site ${ }^{31}$, the distance is approx. $490 \mathrm{~m}$. At first glance, it may seem that this is quite far away, but Pseudo-Apollodoros says that Amphiaraos took flight near the Ismenos River only; respectively, he could have covered some distance from the river before the earth opened and swallowed him. In order to suggest the track of Amphiaraos, it is necessary to correlate the gates that he attacked with both the Ismenos River and the localizations of the place where the hero was swallowed by the earth, and analyze the logic of his movements (and if there is any at all?). Aischylos places Amphiaraos in

authors, which is not critical for the localization of the place indicated by Pausanias, see: Renberg (2017). P. 667-668, n. 18.

${ }^{26}$ Mozhajsky (2014). P. 77-78; Renberg (2017). P. 662-664.

${ }^{27}$ Keramopoullos (1917). P. 261-266; Mozhajsky (2014). P. 78.

${ }^{28}$ Symeomoglou (1985). P. 177-178, 296, pls.8,48.

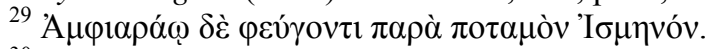

${ }^{30} \mathrm{~A} 1$ in Fig. 1.

${ }^{31}$ A2 in Fig. 1. 
front of the Homoloides gates (Sept. 568-570), and Euripides - at the Proitides gates (Phoen. 1109-111). The situation with the book of Statius is somewhat more complicated, but, indirectly, it appears that Amphiaraos also attacked the Proitides gates ${ }^{32}$. We examined in detail the possible location of the gates in another publication ${ }^{33}$.

In Fig. 1 (P. 194-195), the Homoloides gates are marked as 2, and the Proitides gates, as 3. As for the Homoloides gates, the location of this exit in the middle of the eastern slope of the Kadmeia was theoretically substantiated by Keramopoullos, and after V. Aravantinos discovered here a fragment of the Mycenaean wall with the bastion in 1984, the association of the Homoloides gates with this place received additional support $^{34}$. The location of the Proitides gates is primarily determined in accordance with Pausanias, since they were supposed to be on the road to Chalkis and, as we will see, this is the most important message for us that interprets Euripides' version (Paus. 9.18.1). In both cases, the Ismenos is at a fairly close distance from the gates - approx. $300 \mathrm{~m}$. A comparison of the location of the gates with the connecting roads suggests that, regarding the movement of Amphiaraos from the Ismenos to the place where he was swallowed in Aischylos, a version is supported that is consistent with the Theban version of Pausanias' $\pi \varepsilon \rho i \beta$ ß natural way for Amphiaraos to retreat from these gates, without crossing the Ismenos river, lies along the walls of the Kadmeia to the south and then a little southwest to get on the road from the Kadmeia to Potniai, and then through Plataiai to Attica or Peloponnese. It is here, between the Kadmeia and Potniai, that the place where, according to the Theban version, the earth swallowed Amphiaraos is most probably located. If we accept Euripides' message that Amphiaraos attacked the Proitides gates, a natural and short route for him to retreat was on the road to Chalkis, which goes from these gates through Harma (Paus. 9.18.1; 1.34.2).

Thus, this tradition is consistent with the "Tanagrian" version of Amphiaraos' retreat we have identified. However, if so, then the question

${ }^{32}$ Statius mentions Hypseus as the defender of the Proitides gates (Theb. 8. 353-357). Hypseus opposes Amphiaraos (Theb. 7. 690-735).

${ }^{33}$ Mozhajsky (2018).

${ }^{34}$ Keramopoullos (1917). P. 475-477; Aravantinos (1988); Mozhajsky (2018). P. 87-92. 
should be answered: how did this version get into Euripides' writings? It should be noted that the tragedy The Phoenician Women by Euripides was very popular in antiquity, as evidenced by its reproduction in numerous papyri (which surpass in number those of any other tragic texts), its rich pictorial representations from the late third century, as well as its parody in an homonymous comedy by Aristophanes (fr. $570 \mathrm{~K}-\mathrm{A})^{35}$. Researchers suggest that the tragedy was first staged in 411,410 or 409 $\mathrm{BC}^{36}$. This means that the time of the tragedy creation coincides with the period when the oracle of Amphiaraos in Oropos began functioning, which, as we mentioned, probably happened at approx. 420-414 BC. As you know, in this period Oropos was controlled by Athens, and the "Tanagrian" version of the disappearance of Amphiaraos could have easily become popular in Athens, which, in our opinion, was reflected in The Phoenician Women by Euripides. Starting from the Late Archaic period, the Oropians were closely associated with the Athenians and depended on them in different periods ${ }^{37}$. In addition, in $412 / 411 \mathrm{BC}$ the political agenda reminded the Athenians of Oropos, since at that moment Oropos was captured by the Boiotians ${ }^{38}$.

\section{KAPANEUS AND THE ELEKTRAI GATES}

In paragraphs 4-6 of the eighth chapter, Pausanias talks about the seven gates of Thebes, explaining their names. The most interesting pas-

${ }^{35}$ Lamari (2017). P. 258. This explains the penetration of the "Tanagrian" version of the disappearance of Amphiaraos into the writings of later authors through Euripides. Popularity also influenced the pedagogical significance of The Phoenician Women, since Byzantine scholars appreciated its didactic potential and selected it as one of the three Euripidean tragedies (known as the Byzantine triad) that would be taught in schools and reproduced in hundreds of copies, see: Cribiore (2001), Cribiore (2018), Lamari (2017). P. 258.

${ }^{36}$ Lamari (2017). P. 259-260.

${ }^{37}$ Buck (1979). P. 123, 143, 153, 173; Mozhajsky (2007). C. 59, 100-101; van Wijk (2019). P. 174-178. It should be noted that van Wijk assumes that the sanctuary of Amphiaraos had always been located in Oropos, see: van Wijk (2019). P. 175-176, n. 858. Cf. Schachter (1981). P. 21-23.

${ }^{38}$ Buck (1994). P. 19, 23; Mozhajsky (2007). P.134-135; van Wijk (2019). P. 179. 


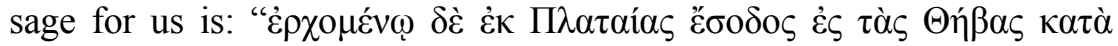

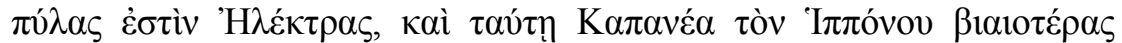

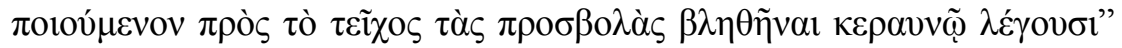
("The entry into Thebes from Plataea is by the Electran gate. At this, so they say, Capaneus, the son of Hipponous, was struck by lightning as he was making a more furious attack upon the fortifications") (Paus. 9.8.7; translated by W.H.S. Jones.).

Thus, according to Pausanias, the Thebans directly connected the Elektrai gates with Kapaneus and the place of his death. At the site of the legendary gates, Keramopoullos unearthed the gates of the Classical early Hellenistic period. Keramopoullos ${ }^{39}$ himself, taking into account the history of Thebes and the ceramic material apparently dating back to the time of the construction of the western tower, attributed the construction of the towers to the period of restoration of Thebes by Kassandros in 316 BC, but, as Symeonoglou notes, the wall of isodomic masonry attached to the western tower was two meters thick and it could have belonged to the Classical period ${ }^{40}$.

What pedagogical tradition is recorded in this message by Pausanias? First of all, we are talking about the place of military valour of both Kapaneus and those who fought off his frantic attack on the Elektrai gates. The very association of Kapaneus with the Elektrai gates corresponds to both Aischylos' (Sept. 423, 447-448) and Euripides' (Phoen. 1128-1129) texts, where Polyphontes opposed Kapaneus. In addition, Pausanias' text emphasizes an educational moment, according to which Kapaneus was struck by lightning for mocking the gods, including Zeus himself, which is also reflected in Aischylos (Sept. 440-446) and Euripides (Phoen. 1172-1186). Thus, the Elektrai gates, as represented by the second-century AD Thebans, continued to be an edifying reminder of the punishment for disrespect for the gods.

It should be noted that the Elektrai gates in Thebes were perhaps the most monumental evidence of material culture that reflected the story of Seven against Thebes (at least, reflecting the story of Kapaneus and his attack on the city). However, the association of Kapaneus with the Elektrai gates was preserved in a wide range of monuments and artifacts.

${ }^{39}$ Keramopoullos (1917). P. 7-52.

${ }^{40}$ Symeomoglou (1985). P. 236; Mozhajsky (2018). P. 89-90. 
The surviving images of Kapaneus on the objects of material culture reflect the fact that walls, gates or ladders are the main attributes of Kapaneus. So, the image of Kapaneus falling from the ladder is captured on the relief from the heroon of Trysa dating 410-400 $\mathrm{BC}^{41}$. It is estimated that out of about nineteen known evidence of material culture that depict a warrior with a ladder or on a ladder, sixteen are relatively accurately associated with Kapaneus, but only a few of them show him falling from the ladder ${ }^{42}$. In this regard, this image is unique.

Red-figure ceramics also has images of Kapaneus. Notable is the Campanian neck-amphora attributed to Caivano Painter, approx. 340 BC, Fig. 2 (P. 196) ${ }^{43}$, because on this amphora, in addition to Kapaneus on the ladder, the gate is depicted. A special case in terms of the number of artifacts is Etruria, where scenes from Seven against Thebes became popular since the beginning of the fifth century BC. During the fifth century, interest in this story in Etruscan art only grew due to the Athenian theater $^{44}$. The image of Kapaneus is also present in Etruria during the Hellenistic period, such as, for example, on the terracotta pediment from Talamone (second quarter of the second century BC) in Florence ${ }^{45}$. A similar scene and other scenes depicting Kapaneus on a ladder near the walls or the Elektrai gates can be seen on Etruscan ash urns (second-first century $)^{46}$. We are familiar with several sarcophagi, dating back to Roman times, on which Kapaneus is depicted with a ladder or climbing the walls of Thebes. One of them is a marble sarcophagus of Roman times

${ }^{41}$ We follow Landskron's dating. On the traditional dating and probable dating to an earlier time, see: Landskron (2015). P. 347-349.

${ }_{42}^{4}$ Landskron (2015). P. 87-88.

${ }^{43}$ Krauskopf (1990). P. 954, n. 12a.

${ }^{44}$ Simon (2013). P. 502-504.

${ }^{45}$ In the center there is Oidipous, who fell to his knees between his dying sons, Eteokles and Polyneikes. Behind him is the wall of Thebes with Kapaneus on the stairs. On the right, the earth swallows Amphiaraos with his chariot. On the left, Adrastos drives his horses the other way, see: Krauskopf (1994). P. 741, n. 48; Simon (2013). P. 508.

${ }^{46}$ One of these ash urns is in Fig. 3 (P. 197), for the description, see: Digital LIMC https://www.weblimc.org/page/monument/2084118 (August, 2020). Cf. others urns, on which Kapaneus attacking the walls is depicted, see: Körte (1890). P. 56-70, tav. 20,8-24. 
(L. 2.20, H. 1.24), dating from 140-160 AD. It was found in Corinth and is kept in the Archaeological Museum of Corinth (Digital Lexicon Iconographicum Mythologiae Classicae: https://www.weblimc.org/page/ monument/2070915 [August, 2020]). This is definitely a Greek-style sarcophagus which was most likely produced in Athens. The sarcophagus we are considering has a pronounced Greek style ${ }^{47}$. In addition, according to Young, the images on the sarcophagus were based on the models of the Classical period, and the relief style probably belongs to a Greek master, who, despite working under the influence of Roman art, nevertheless relied on old Hellenic ideals ${ }^{48}$. This sarcophagus depicts all seven warriors attacking Thebes. One of the fully armed warriors carries a ladder on his left shoulder and is thus identified as Kapaneus. On the marble sarcophagus (end of the second century AD, L.1.92, H. 0.47), which is located in Rome (Villa Doria Pamphilj), he is also depicted with his right foot standing on the ladder ${ }^{49}$. It should be noted that these sarcophagi date back to the time of Pausanias himself and, thus, clearly capture the tradition of the image of Kapaneus characteristic for this time, which is connected specifically with the walls of Thebes ${ }^{50}$. In this regard, the Elektrai gates become the object of the visualization of the Kapaneus story and have double symbolism: on the one hand, they remind of valour (both of attacking Kapaneus and the defending Thebans), and on the other hand, they serve as a reminder of retribution for the inappropriate attitude towards the gods and arrogance.

\section{THE ROAD FROM THEBES TO CHALKIS}

Pausanias returns to the description of Theban monuments related to

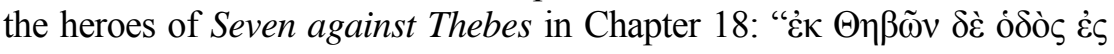

${ }^{47}$ Young (1922). P. 441-444; Johnson (1931). P. 116-119; Pichugina, Mozhajsky (2020). P. 114-115.

${ }^{48}$ Young (1922). P. 442; Pichugina, Mozhajsky (2020). P. 112-113.

${ }^{49}$ Robert (1890). P. 193-195, №184, pl. 60; Sichtermann, Koch (1975). P. 67-68, №73, pl. 172; Calza et al. (1977). P. 169, №197, pl. 121; Pichugina, Mozhajsky (in print).

${ }^{50}$ A gemma (inv. B 100) from the collection of Corpus Christi College, Cambridge, which most likely depicts Kapaneus falling from the walls of Thebes (the walls are also depicted). It is also related to Roman time, see: Middleton (1892). P. 68. 


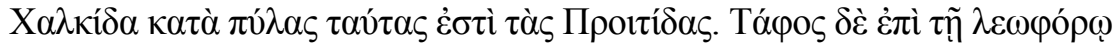

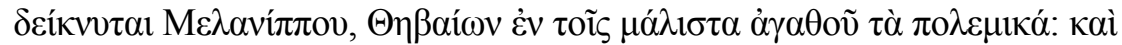

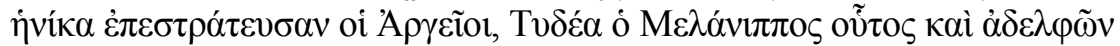

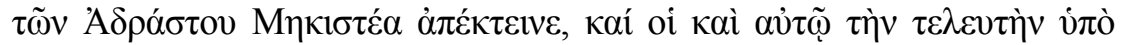

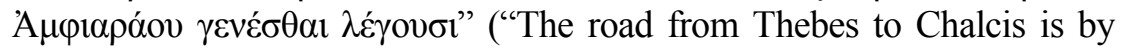
this Proetidian gate. On the highway is pointed out the grave of Melanippus, one of the very best of the soldiers of Thebes. When the Argive invasion occurred this Melanippus killed Tydeus, as well as Mecisteus, one of the brothers of Adrastus, while he himself, they say, met his death at the hands of Amphiaraus") (Paus. 9.18.1; translated by W.H.S. Jones).

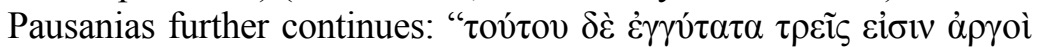

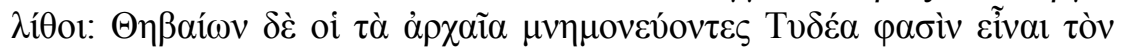

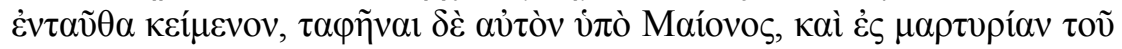
$\lambda$ ó $\kappa \alpha \lambda v ́ \pi \tau \varepsilon$ " ("Quite close to it are three unwrought stones. The Theban antiquaries assert that the man lying here is Tydeus, and that his burial was carried out by Maeon. As proof of their assertion they quoted a line of the Iliad: "Of Tydeus, who at Thebes is covered by a heap of earth") (Paus. 9.18.2; translated by W.H.S. Jones).

As one can see from these fragments by Pausanias, Melanippos and Tydeus are associated with the Proitides gates. This is consistent with the tradition captured by Aischylos, where Tydeus attacks the Proitides gates and Melanippos from Thebes confronts him (Sept. 377-416). As it has already been shown by the example of Theban monuments associated with Amphiaraos, the Theban guides of Pausanias, in the case of Melanippos and Tydeus, followed the version reflected by Aischylos in their topography. Given this sequence of Pausanias' informants, we can assume that Aischylos was familiar with the Theban version of the association between the gates and the heroes. As for the location of the tomb of Melanippos and the stones, which indicated the burial place of Tydeus according to the second-century AD Thebans, these places should have been in the vicinity of the Kastellia hills. This assumption is based on the probable location of the Proitides gates and the road to Chalkis ${ }^{51}$. The

${ }^{51}$ Symeonoglou (Symeonoglou (1985). P. 193), following Keramopoullos (Keramopoullos (1917). P. 361), assumes that in ancient times the road to Chalkis passed between the two hills of Kastellia. 
only evidence of the monument location is that, according to Pausanias, the tomb of Oidipous' children was located next to the tombs of Melanippos and Tydeus, which, in turn, was 2500-2700 $\mathrm{m}$ in front of the tomb of Teiresias, which, in turn, should have been located outside Greater Thebes abandoned during the times of Pausanias ${ }^{52}$. According to Faraklas, it is likely that somewhere at the foot of Mikro Kastelli, the Thebans showed the grave they believed to be the tomb of Melanippos, which could have been a Mycenaean chamber tomb ${ }^{53}$. Next to it, they showed a place associated with the tomb of Tydeus ${ }^{54}$. Thus, we see a place associated by the Thebans with the warrior who attacked Thebes and the warrior who defended Thebes. Pausanias notes that Tydeus was killed by Melanippos. Accordingly, since the Thebans showed visitors the tomb of Tydeus, then, as Symeonoglou noted, this was to symbolize the power of Thebes over the defeated Argos ${ }^{55}$. This is important for our research, since we believe that the demonstration of Theban power through monuments associated with the enemy (including the place where the earth swallowed Amphiaraos and the place where Kapaneus was struck by lightning) was intended not only for visitors from other regions, but, first of all, for their own fellow citizens. We are talking about cultivation of patriotism and military valour. Moreover, on the one hand, the valour of the Theban warriors who defeated the enemy was emphasized; on the other hand, the enemy was also valiant, i.e. valour fostered valour.

We believe that in Thebes, the monuments associated with the enemy were as sacred as the monuments associated with their own Theban heroes. Amphiaraos became a sacred figure in Thebes, and we believe that a number of other attackers too. This is even more likely since Pausanias tells of Hektor whose tomb was also in Thebes. According to the version told by Pausanias, the oracle said that the Thebans would live in prosperity if they brought Hektor's bones from Ilion to Thebes and wor-

${ }^{52}$ Faraklas (1998). P. 139.

${ }^{53}$ Faraklas (1998). P. 139.

${ }^{54}$ Symeonoglou notes that Pausanias is very careful about the definition of this grave and reports that near the tomb of Melanippos, he saw three stones, "which, according to the Theban antiquarians, mark the tomb of Tydeus", see: Symeomoglou (1985). P. 194.

${ }^{55}$ Symeomoglou (1985). P. 194. 
shipped him as a hero (Paus. 9.18.5) ${ }^{56}$. It is interesting that not only Thebes worshipped the epic opponents from Seven against Thebes, but there was also a reverse process. So, according to Herodotos (5.67), Kleisthenes, the tyrant of Sikyon, established the cult of Melanippos ${ }^{57}$. Pausanias further reports that next to the tombs of Melanippos and Tydeus is the tomb of the sons of Oidipous, and 15 stadia from this place is the tomb of Teiresias (Paus. 9.18,3-4) ${ }^{58}$. As for the tombs of Eteokles and Polyneikes, the researchers proposed to interpret a large chamber tomb with two entrances to Megalo Kastelli as the one shown to Pausanias $^{59}$. We cannot judge if this is the same tomb. However, in terms of its characteristic features, it stands out among others. This tomb is the largest tomb of this type and is unique due to the rich wall paintings ${ }^{60}$. According to Aravantinos, this tomb did not originally have two entrances:

${ }^{56}$ Farnell attributes the establishment of the cult of Hektor in Thebes to the period of the Greco-Persian Wars, around the time of the Battle of Plataiai, see: Farnell (1921). P. 328-329. Other researchers attribute the establishment of the cult to the Hellenistic period, see: Schachter (1981). P. 233-234 (note that Schachter provides the historiography of the issue); Alcock (1997). P. 27-28.

${ }^{57}$ Farnell shares the version of Herodotos that Kleisthenes established the cult of Melanippos in order to abolish the cult of Adrastos in Sikyon, as Adrastos was an Argive, see: Farnell (1921). P. 335.

${ }^{58}$ It is impossible to reconstruct the probable location of the cenotaph of Teiresias. We did not just measure 15 stadia from Megalo Kastelli on the road to Chalkis (this direction might have been correct, though). Obviously, the cenotaph of Teiresias was located outside Greater Thebes.

${ }^{59}$ Symeomoglou (1985). P. 194; Aravantinos states that identification is not safe and of no good service to scholarship, see: Aravantinos (2015b). P. 26-27, no. 43 .

${ }^{60}$ Of particular note is the scene with, probably, a sitting woman who has her head bent and raises her hands over it in a gesture of respect or greeting, while behind her is an architectural façade and bands floating like flags. Aravantinos observes: "The careful cleaning and study of plaster fragments has revealed that two more female figures were surely depicted in a second zone under the seated figure. These two face each other in the same posture of veneration, but in this case they stand upright, while the vague traces of similar painted decoration that are visible in between them probably indicate that there was a third standing woman in an unknown pose", see: Aravantinos et al. (2018). P. 437-440. 
the second (eastern) entrance was added later and the burial chamber was enlarged by approx. mid XIII century BC. Aravantinos believes that the interpretation of the extant evidence as the result of the refurbishment of a pre-existing state monument is the only one plausible ${ }^{61}$. The most important characteristic of this burial for our research is that, as Symeonoglou notes, "there was evidence that the chambers were used from Archaic to the Hellenistic period" $"$. Accordingly, the population of Thebes noted this tomb already in the Archaic period. Given the monumental size of the tomb, the rich fresco painting and two entrances, there is a possibility that this place could have been associated with the tombs of Eteokles and Polyneikes in the Archaic period (or later).

\section{THE TOMB OF ASPHODIKOS}

We have already mentioned the tomb of Hektor, which is located at

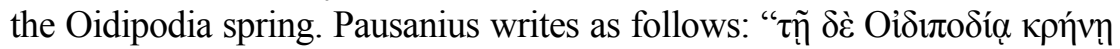

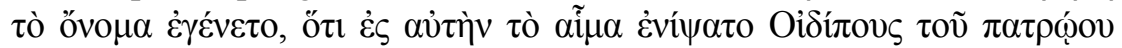

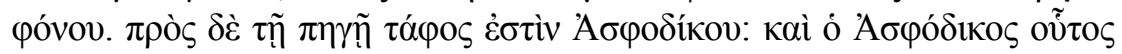

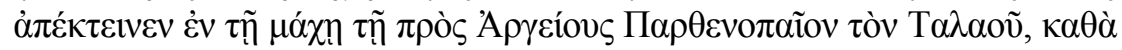

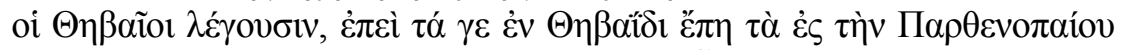

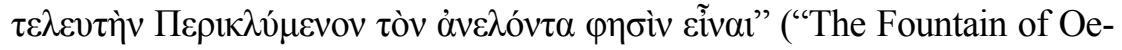
dipus was so named because Oedipus washed off into it the blood of his murdered father. Hard by the spring is the grave of Asphodicus. He it was who in the fighting with the Argives killed Parthenopaeus, the son of Talaus. This is the Theban account, but according to the passage in the Thebaid which tells of the death of Parthenopaeus it was Periclymenus who killed him") (Paus. 9.18.6; translated by W.H.S. Jones).

Symeonoglou identifies the Oidipodia spring as the modern fountain at Agioi Theodoroi (site 244 in Symeonoglou's catalog, O1 Fig.1). The grave of Asphodikos could have been located on the closest to the spring side of the Kastelli hills. Aravantinos' article, The Palatial Administration of Thebes Updated, presents a map of Mycenaean cemeteries of chamber tombs around the citadel ${ }^{63}$. Symeonoglou suggests (and if we

\footnotetext{
${ }^{61}$ Aravantinos (2015b). P. 30.

${ }^{62}$ Symeomoglou (1985). P. 305.

${ }^{63}$ Aravantinos (2015b). P. 25. Fig. 5.
} 
use this map) that, the tomb of Asphodikos should have been located on the northeast corner of Mikro Kastelli. However, this identification has its weaknesses. Firstly, the northeast corner of Mikro Kastelli is closer to the probable tombs of Melanippos and Tydeus, as well as to the tomb with two entrances (the so-called tomb of Oidipous' children) than to the spring at Agioi Theodoroi. Would Pausanias really have tied this tomb to this spring if it had been closer to other significant monuments? Secondly, the literary tradition connects the murder of Laius by Oidipous with the road to Delphi (or, less commonly, with the road to Potniai). It would have been strange if the spring where Oidipous washed the blood after the murder of Laios had been on the road to Chalkis. In this regard, it was Faraklas who proposed an interesting identification of the spring location $^{64}$. In his opinion, the spring, the fountain and two tombs (Asphodikos' and Hektor') should have been located on the road to Delphi, and the fragment where Pausanias reports about these monuments does not refer to this narration but was inserted later. Thus, Faraklas believes that the Oidipodea spring and, accordingly, the tomb of Asphodikos were located to the northwest of the citadel. He associates the Oidipodea with the spring of Vrysoula ${ }^{65}$. We marked this position of the spring and the tomb in Figure 1 as $\mathrm{O} 2$ and As2, respectively. This version can also be criticized. We did not find information about any known Mycenaean tombs near Vrysoula. However, if the tomb of Asphodikos was a monument of Hellenistic times (probably, like the tomb of Hektor, especially since they were located nearby), this could explain the absence of Mycenaean tombs. It seems that this point of view may be quite relevant.

It should be noted that the Thebans who showed Pausanias the tomb of Asphodikos emphasized his military valour and said that it was he who had killed Parthenopaeus. Apparently, this was the main reason why they showed this monument, especially since, according to Pausanias, these facts differed from the information given in The Thebaid.

${ }^{64}$ Faraklas (1998). P. 140-141.

${ }^{65}$ Faraklas (1998). P. 151, 167-168. Fig. 8.3. 


\section{IN FRONT OF THE NEISTAI GATES}

Pausanias $(9.25,1-2)$ mentions a group of monuments related to the story of Seven against Thebes, between the Neistai gates and the Dirke river, which are therefore easily localized. We are talking about the tomb of Menoikeus and the place where the duel between Eteokles and Polyneikes took place (marked by a pillar with a stone shield on it). The entire area was called Syrma ("dragging") because, according to Pausanias, from here Antigone dragged the body of Polyneikes to the funeral pyre of Eteokles. Indeed, given the location of the Neistai gates, it can be understood that we are talking about a stretch of land between the river and the Kadmeia slopes, 50 to 100 meters wide ${ }^{66}$. I should be noted that according to Aischylos (Sept. 631, 800), the duel between Eteokles and Polyneikes took place at the seventh gate, while according to Euripides (Phoen. 1570), they fought at the Elektrai gates. In our opinion, Symeonoglou correctly observes that "it is unclear whether there was a gate named Hebdomai, or whether Aischylos simply meant the seventh gate of Thebes" ${ }^{\prime 67}$. However, if Aischylos meant that the duel took place at the seventh gate by number, this version could have coincided with the one retold to Pausanias by the Thebans. In any case, we see that there existed several traditions.

Why are these two monuments meaningful for our research? First of all, the tomb of Menoikeus could have been identified with self-sacrifice for the sake of the hometown. The place of the duel between the sons of Oidipous could have had many meanings: to warn against internecine violence, to serve as a place of grief and reconciliation in death. The latter is supported by the name of this place - the Syrma of Antigone, after the sister who "reconciled" the brothers in a funeral pyre.

\section{CONCLUSION}

Albert Schachter justly noted that Pausanias saw some monuments in Thebes as "allegedly connected with the Wars of the Seven and the Epigonoi, conveniently grouped together along the highroads to Chalkis and the east, while sites connected with the foundation of Thebes by

\footnotetext{
${ }^{66}$ Symeomoglou (1985). P. 196.

${ }^{67}$ Symeomoglou (1985). P. 197.
} 
Kadmos were similarly grouped for the benefit of travellers, south of the Kadmeia, near the road from Athens" ${ }^{\text {"68 }}$. Schachter underscored the largest cluster of monuments related to the story of the Seven, but there are some other individual monuments and clusters present in Pausanias' texts. On the south and southeast slopes of the Kadmeia there were places associated with Amphiaraos and Kapaneus, and on the northwest side there were monuments and places associated with the children of Oidipous, Menoikeus, and possibly Oidipous and Asphodikos himself (if we accept Faraklas' point of view). It is interesting to look at the distance that separated these monuments from the citadel. Most of the monuments were in the vicinity of the Kadmeia gates (up to $260 \mathrm{~m}$ ). In a few particular cases, the monuments could have been located farther from the gates. For example, according to Symeonoglou, the sacred place where Amphiaraos was swallowed by the earth was located about 300 meters from the Hypsistai (or the Onkaiai?) gates, and according to Keramopoullos, approx. $960 \mathrm{~m}$. If any of these identifications is correct, this distance could reflect the literary tradition of the retreat of Amphiaraos.

If the proposed localizations are correct, the distance from the gates to the Oidipodia spring is also consistent with the literary tradition, since it was supposed to be on the way to the Kadmeia (according to Symeonoglou, approx. $510 \mathrm{~m}$ from the Proitides gates, or, according to Faraklas, approx. $500 \mathrm{~m}$ from the Neistai gates, and approx. $470 \mathrm{~m}$ from the Borraiai gates (or the Ogygiai gates?). In addition, some of the monuments could have a real connection with the Mycenaean time, such as the probable tombs of Melanippos and the children of Oidipous on the Kastellia hills. Thus, we see the close circle of monuments (near the gates of the Kadmeia) and the far circle of monuments (at a distance of 300 to $500-960 \mathrm{~m}$ from them). There is also a monument that does not fit into this scheme. It is the cenotaph of Teiresias, which was supposed to be at a distance of 2500-2700 m next to the tomb of Oidipous' children.

Regarding the place where the earth swallowed Amphiaraos, Pausanias refers to two traditions: the "Theban" and the "Tanagrian" ones. In our opinion, the "Tanagrian" version could be adapted by the Oropians and the Athenians as more beneficial for the oracle of Amphiaraos in Oropos. The

${ }^{68}$ Schachter (2008). P. 649; Schachter (2016). P. 133. 
topographical data show that the Theban version is consistent with the tradition reflected in Aischylos' Seven against Thebes, while the "Tanagrian" version is captured in Euripides' The Phoenician Women.

As for Kapaneus, the Elektrai gates were a monument of valour for the Thebans, and a specific reminder of the punishment for the inappropriate attitude towards the gods at the same time. The connection of Kapaneus with the gates is illustrated by numerous evidence of material culture, including images on the sarcophagi of Pausanias' times.

As it has already been noted, the largest cluster of monuments associated with the history of Seven against Thebes was located on the road to Chalkis. The largest of the chamber tombs, the one with two entrances and rich murals, should perhaps be identified with the tomb the Thebans considered the grave of the children of Oidipous, mentioned by Pausanias. At least, the researchers observe that there is evidence of its use from Archaic to Hellenistic times.

For our research, the monuments of Melanippos and Tydeus are very important, since they symbolize, first of all, the military valour of the Thebans embodied by Melanippos, who, according to the Thebans, killed Tydeus and one of Adrastos' brothers. Topographically, these monuments are connected with the Proitides gates, and this again corresponds to the tradition described by Aischylos. Presumably, the playwright reflected the Theban version of the attack of the Argives on the gates of Thebes.

The same motive of military valour is characteristic of the Asphodikos monument, wherever it was located (on the northeast or northwest slopes of the Kadmeia). The Thebans pointed out to Pausanias that, according to their version, it was Asphodikos who killed Parthenopaeus. We suggest that if this monument was located on the northwestern slope of the Kadmeia, then, taking into account the absence of Mycenaean burials here and the presence of the Hellenistic cult of Hektor, the grave of Asphodikos could also date from Hellenistic times.

Many of the monuments associated with the story of Seven against Thebes were symbols of military valour and glorified the Thebans in their victory over the Argives. However, there were several monuments that transcended this meaning. These monuments were at the Neistai gates. The first one is the tomb of Menoikeus, which symbolizes self-sacrifice for the sake of the hometown (not necessarily military). The second monument is the place of the duel between Eteokles and Polyneikes, indicated by a his- 
torical monument in the shape of a pillar with a stone shield on it. This monument could have had ambiguous meaning: it warned against internecine feuds and could be a place of grief and reconciliation in death.

We believe that all these monuments were not only shown to travellers, such as Pausanias, but were also a part of the local educational practice that clearly demonstrated the Theban mythological history. 


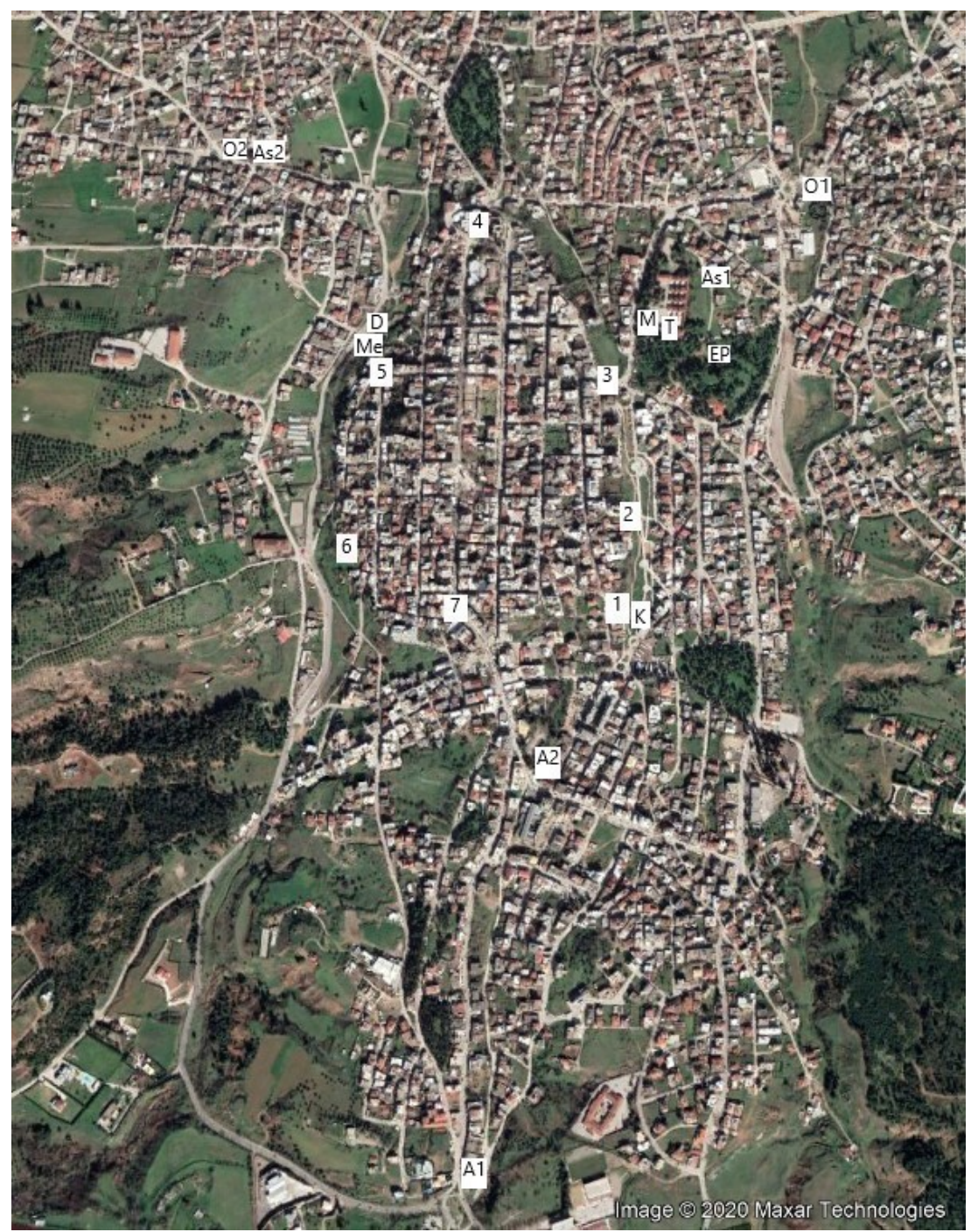

Fig. 1.

General map. Map data: Google, DigitalGlobe. 
1 - the Elektrai gates. 2 - the Homoloides gates. 3 - the Proitides gates. 4 - the Borraiai gates (or the Ogygiai gates?). 5 - the Neistai gates. 6 - the Krenaiai gates. 7 - the Hypsistai gates (or the Onkaiai gates?). A1 - the place where the earth swallowed Amphiaraos (according to Keramopoullos). A2 - the place where the earth swallowed Amphiaraos (according to Symeonoglou). K the place where lightning struck Kapaneus. $\mathrm{M}-$ a possible location of the tomb of Melanippos. T - a probable location of the place which the Thebans considered the tomb of Tydeus. EP - the tomb which the Thebans could identify with the grave of Eteokles and Polyneikes. As1 - a probable location of the tomb of Asphodikos (adapted by me from the text by Symeonoglou). As2 - a probable location of the tomb of Asphodikos (adapted by me from the text by Faraklas). O1 - the Oidipodia spring (according to Symeonoglou). $\mathrm{O} 2$ - the Oidipodia spring (according to Faraklas). Me - a probable location of the tomb of Menoikeus. D - a probable location of the place where Eteokles and Polyneikes killed each other in a duel (according to Pausanias). 


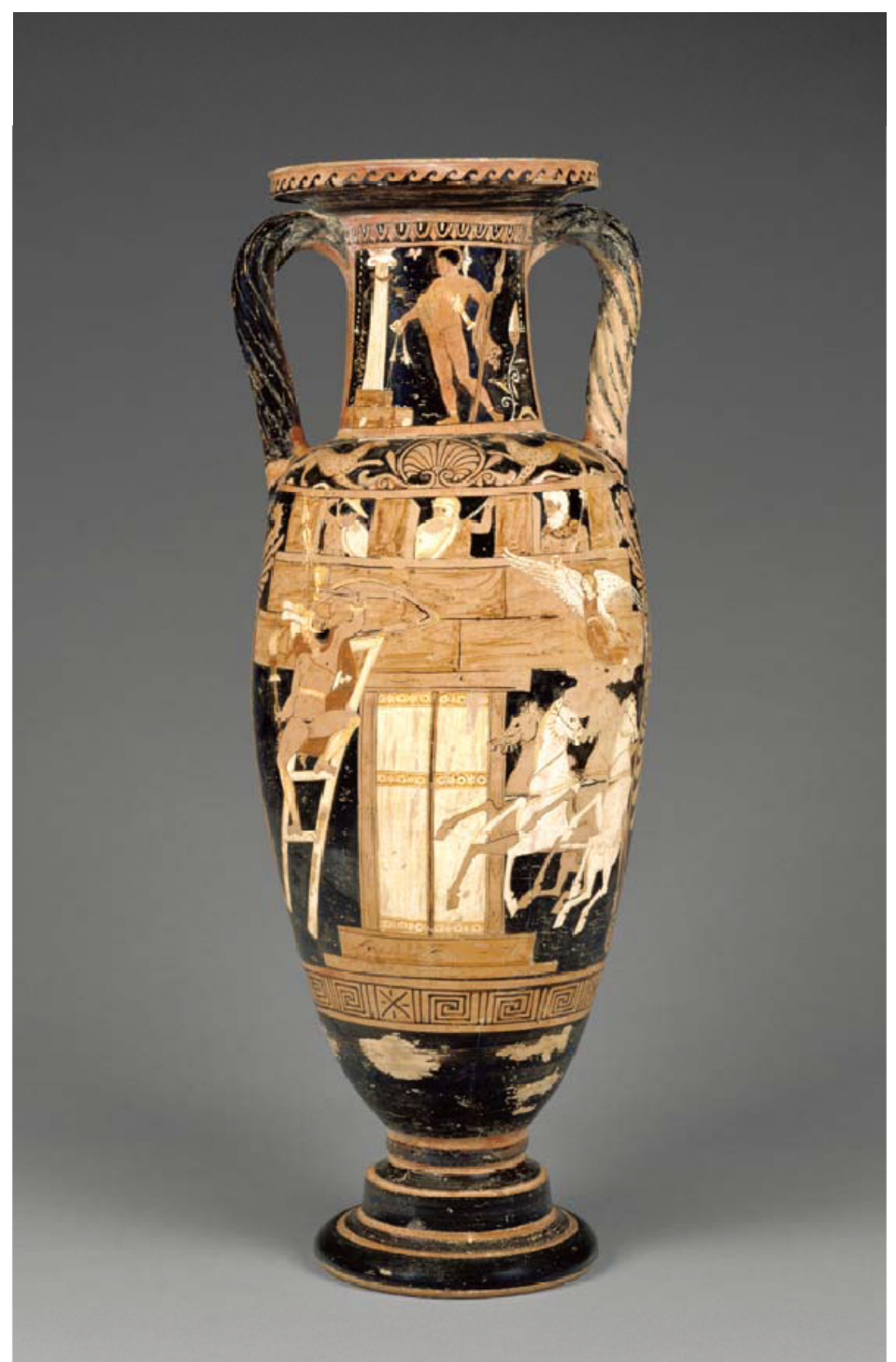

Fig. 2.

Campanian Neck-Amphora, about 340 B.C. Inv. 92.AE.86. The J. Paul Getty Museum, Villa Collection, Malibu, California. Digital image courtesy of the Getty's Open Content Program. 


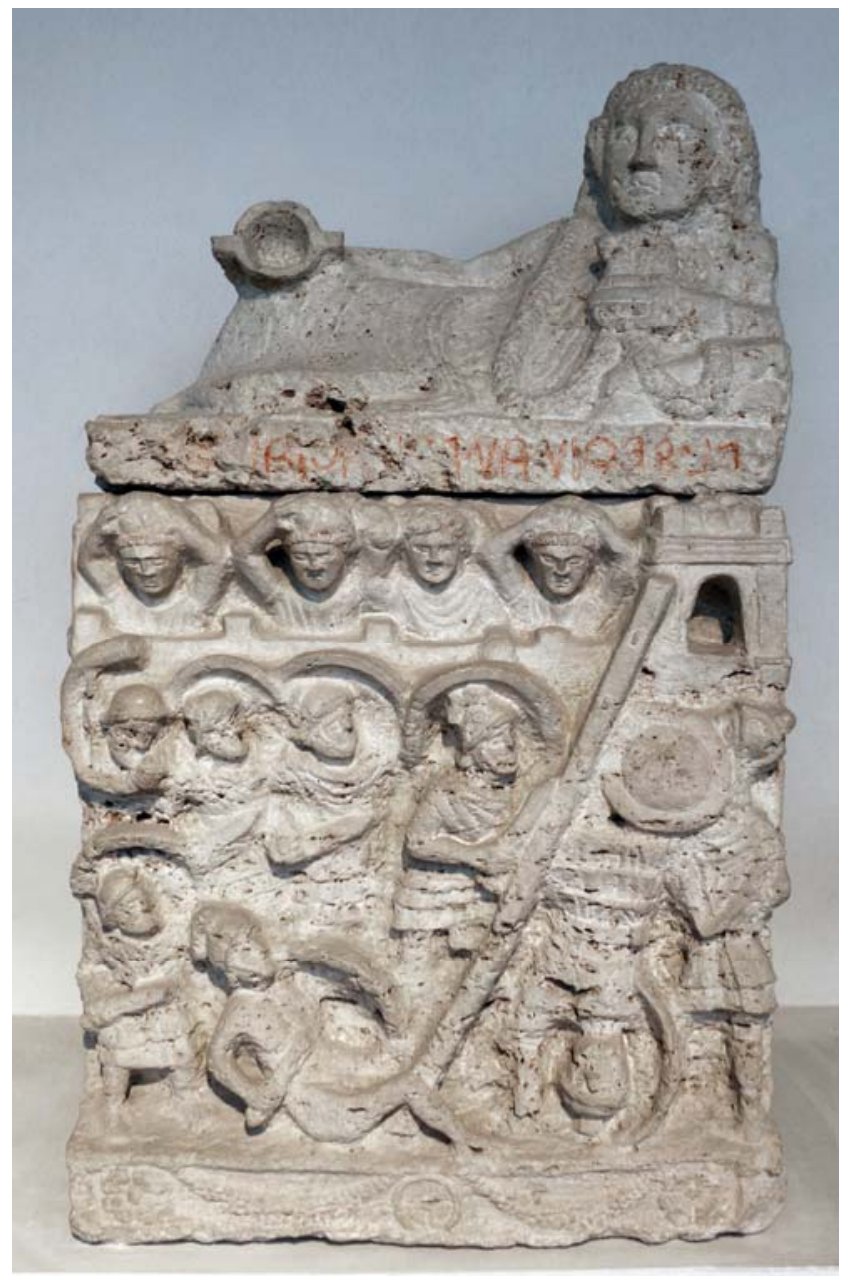

Fig. 3.

Etruscan ash urn. Museo Archeologico Nazionale dell'Umbria Perugia. Inv. 321.

Source: https://upload.wikimedia.org/wikipedia/commons/3 $/ 32 /$ Urna di vel fethiu con assedio alle mura di tebe $\% 2 \mathrm{C} \_110$ 90 ac ca. $\% 2 \mathrm{C}$ da ipogeo dei rufi presso perugia 01.jpg (August, 2020). Wikimedia Commons / Sailko / CC BY-SA (https:// creativecommons.org/licenses/by-sa/4.0 [August, 2020]). 


\section{БИБЛИОГРАФИЯ И ЕЕ СОКРАЩЕНИЯ}

Оригинальные тексты литературных источников приведены по базе данных классических текстов "The Perseus Digital Library".

Alcock (1997) - Alcock S.E. The Heroic Past in a Hellenistic Present // Hellenistic Constructs. Essays in Culture, History and Historiography / Eds. P. Cartledge, P. Garnsey, E. Gruen. Berkeley Los Angeles, and London: University of California Press, 1997.

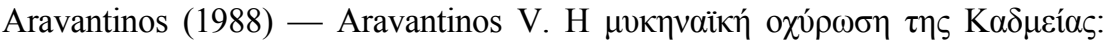

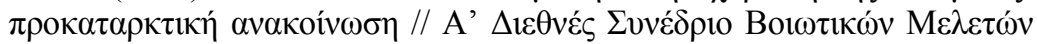

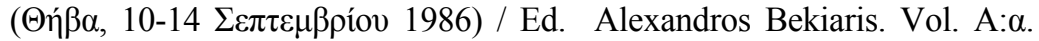
Athens, 1988. P. 113-136.

Aravantinos (2014) - Aravantinos V. The Inscriptions from the Sanctuary of Herakles at Thebes: An Overview // The Epigraphy and History of Boeotia: New Finds, New Prospects $=$ Brill Studies in Greek and Roman Epigraphy Volume 4 / Ed. N. Papazarkadas. Leiden \& Boston: Brill, 2014. P. 149-210.

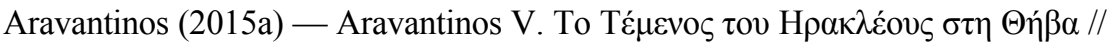

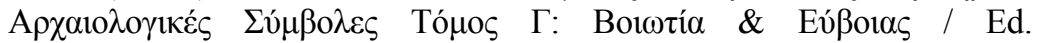
S. Oikonomou. Athens: Museum of Cycladic Art, 2015. P. 85-106.

Aravantinos (2015b) - Aravantinos V. The Palatial Administration of Thebes Updated // Tradition and Innovation in the Mycenaean Palatial Polities (Mykenische Studien 34) / Eds. F. Ruppenstein, J. Weilhartner. Vienna: Österreichische Akadamie der Wissenschaften, 2015. P. 19-49.

Aravantinos (2017) - Aravantinos V. The sanctuaries of Herakles and Apollo Ismenios at Thebes: new evidence // Interpreting the Seventh Century BC. Tradition and Innovation / Eds. X. Charalambidou and C. Morgan. Oxford: Archaeopress Publishing Ltd., 2017. P. 218-227.

Aravantinos et al. (2018) - Aravantinos V.L., Fappas I., Angelidis P., Louka M., Sepetzoglou N. The Female Figure in the Pictorial Tradition of Mycenaean Boeotia: Critical Overview and Technical Observations // XP $\Omega \Sigma T H P E \Sigma$ / PAINTBRUSHES. Wall-painting and Vase-painting of the Second Millennium BC in Dialogue. Proceedings of the International Conference on Aegean Iconography Held at Akrotiri, Thera, 24-26 May 2013, University of Ioannina / Hellenic Ministry of Culture and Sports - Archaeological Receipts Fund / Ed. A. Vlachopoulos. Athens, 2018. P. 427449 .

Berman (2015) - Berman D.W. Myth, Literature, and the Creation of the Topography of Thebes. Cambridge: Cambridge University Press, 2015. 
Bintliff (1994) - Bintliff J.L. Territorial behaviour and the natural history of the Greek polis // Stuttgarter Kolloquium zur Historischen Geographie des Altertums, 4 / Eds. E. Olshausen, H. Sonnabend. Amsterdam: Hakkert Verlag, 1994. P. 207 - 249.

Bintliff (1999) - Bintliff J.L. Pattern and process in the city landscapes of Boeotia, from Geometric to Late Roman times // Territoire des Cités Grecques (BCH Supplement) / Ed. M. Brunet. Athene: Ecole Française d'Athénes, 1999. P. 15-33.

Buck (1979) - Buck R.J. A History of Boeotia. Edmonton: The University of Alberta Press, 1979.

Buck (1994) — Buck R.J. Boiotia and the Boiotian League, 423-371 B.C. Edmonton: The University of Alberta Press, 1994.

Calza et al. (1977) - Antichità di Villa Doria Pamphilj / Eds. Calza R., Bonanno Aravantinos M., Messineo G., Palma B., Pensabene P. Rome: De Luca, 1977.

Casson (1974) - Casson L. Travel in the Ancient World. London: George Allen and Unwin, 1974.

Champion-Smith (1998) - Champion-Smith V.A. Pausanias in Athens: An Archaeological Commentary on the Agora of Athens. PhD thesis, University College London, 1998.

Cribiore (2001) - Cribiore R. The grammarian's choice: the popularity of Euripides' Phoenissae in Hellenistic and Roman education // Education in Greek and Roman antiquity / Ed. Y.L. Too. Leiden; Boston; Koln: Brill, 2001. P. 241-259.

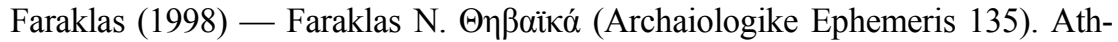
ens, 1998.

Farnell (1921) - Farnell L.R. Greek Hero Cults and Ideas of Immortality. Oxford: Oxford University Press, 1921.

Fossey (1988) - Fossey J.M. Topography and Population of Ancient Boiotia. Chicago: Ares Publishers Inc., 1988.

Frazer (1898) - Pausanias's Description of Greece, translated with a commentary by J.G. Frazer. In six volumes. London: Macmillan and Co., 1898.

Henderson (1923) - Henderson B.W. The Life and Principate of the Emperor Hadrian. London: Methuen, 1923.

Johnson (1931) - Johnson F. Corinth IX, Sculpture 1896-1923. Cambridge, Mass.: Harvard University Press, 1931. 


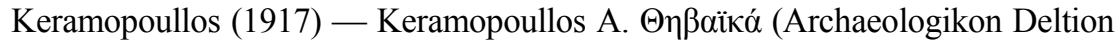
3). Athens, 1917.

Körte (1890) — Körte G. I rilievi delle urne etrusche (Band 2,1). Berlin, 1890.

Krauskopf (1990) - Krauskopf I. Kapaneus // LIMC V. 1990. P. 952-963.

Krauskopf (1994) — Krauskopf I. Septem // LIMC VII. 1994. P. 730-748.

Lamari (2017) - Lamari A.A. Phoenician Women // A Companion to Euripides, First Edition / Ed. Laura K. McClure. Chichester, West Sussex: John Wiley \& Sons Inc., 2017. P. 258-269.

Lamont (2019) - Lamont J.L. The Phenomenon of Incubation in Antiquity // The Classical Review. Vol. 69, Iss. 1, 2019. P. 178-181.

Landskron (2015) - Landskron A. Das Heroon von Trysa. Ein Denkmal in Lykien zwischen Ost und West (Schriften des Kunsthistorischen Museums 13 A), Textband. Wien: Verlag Holzhausen GmbH, 2015.

Middleton (1892) — Middleton J.H. The Lewis collection of gems and rings in the possession of Corpus Christi College, Cambridge, with an introductory essay on ancient gems. London: C.J. Clay \& Sons, Cambridge University Press Warehouse, 1892.

Moggi, Osanna (2010) - Moggi M., Osanna M. Pausania. Guida della Grecia. Libro IX. Milano: Fondazione Lorenzo Valla - Arnoldo Mondadori, 2010.

Mozhajsky (2014) - Mozhajsky A. Yu. The Archaic Wall of Greater Thebes: Chronological and Topographical Problems // Graeco-Latina Brunensia 19, 2014, 2. P. 71-79.

Musti (1988) - Musti D. La struttura del libro di Pausania sulla Beozia // A'

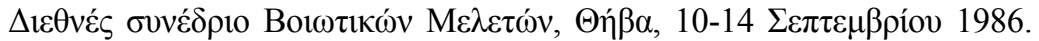
Athens. Vol. I., 1988. P. 333-345.

Osborne (2009) — Osborne R. Greece in the Making, 1200-479 BC. Second edition. London and New York: Routledge, 2009.

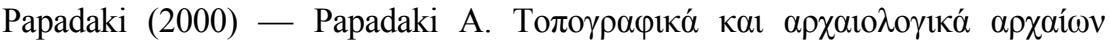

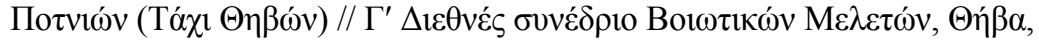
4-8 $\Sigma \varepsilon \pi \tau \varepsilon \mu \beta$ píov 1996. Athens. Vol. I., 2000. P. 357-369.

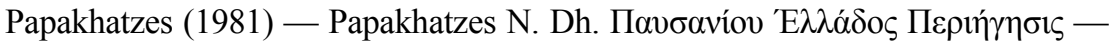
V. Boı

Petropoulou (1981) - Petropoulou A. The Eparche documents and the early oracle at Oropus // GRBS 22, 1981. P. 39-63.

Regenbogen (1956) - Regenbogen O. Pausanias // Realencyclopädie der classischen Altertumswissenschaft. Supplement 8. Edited by August Pauly. Stuttgart: J. B. Metzler, 1956. S. 1008-1097. 
Renberg (2017) - Renberg G. H. Where Dreams May Come. Incubation Sanctuaries in the Greco-Roman World. In two volumes. (Religions in the Graeco-Roman World 184.). Leiden and Boston: Brill, 2017.

Robert (1890) — Robert C. Die antiken Sarkophag-Reliefs II: Mythologische Cyklen. Berlin: G. GROTE'sche verlagsbuchhandlung, 1890.

Schachter (1981) - Schachter A. The Cults of Boiotia 1, BICS Suppl. 38.1. London: Institute of Classical Studies, 1981.

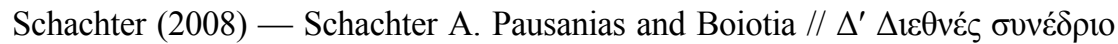

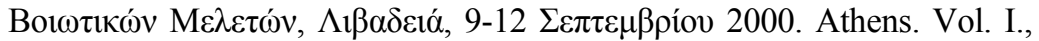
2008. P. 649-664.

Schachter (2016) - Schachter A. Boiotia in Antiquity: Selected Papers. Cambridge: Cambridge University Press, 2016.

Sélincourt (2001) - Sélincourt A. de. The World of Herodotos. London: Phoenix Press, 2001.

Sichtermann, Koch (1975) - Sichtermann H, Koch G. Griechische Mythen auf römischen Sarkophagen. Tübingen: Ernst Wasmuth, 1975.

Simon (2013) - Simon E. Greek Myth in Etruscan Culture // The Etruscan World / Ed. J.M. Turfa. London and New York: Routledge, 2013. P. 495512 .

Symeonoglou (1985). - Symeonoglou S. The Topography of Thebes from the Bronze Age to Modern Times. Princeton: Princeton University Press, 1985.

Tarn (1910) - Tarn W.W. The dedication Ship of Antigonos Gonatas // The Journal of Hellenic Studies, 30 ( 2), 1910. P. 209-222.

van Wijk (2019) — van Wijk R. A Bittersweet Rivalry. The interstate relations between Athens and Boiotia during the Archaic and Classical Period (550323 B.C.E.). Dissertation zur Erlangerung der Doktorwürde an der Philosophischen Fakultät der Universität Freiburg (CH). Pays-Bas, 2019.

Wallace (1979) — Wallace P. Strabo's Description of Boiotia: a Commentary (Strabo). Heidelberg: Winter, 1979.

Wilamowitz-Möellendorff (1883) - Wilamowitz-Möellendorff U. Die Beiden Elektren // Hermes, 18. Bd., H. 2, 1883. P. 214-263.

Wycherley (1982) - Wycherley R.E. Pausanias and Praxiteles // Hesperia Supplement: 20, 1982. P. 182-191.

Young (1922) - Young J.D. A Sarcophagus at Corinth // American Journal of Archaeology, Vol. 26, No. 4, 1922. P. 430-444. 
Крибиоре (2018) - Крибиоре Р. Выбор грамматика: популярность «Финикиянок» Еврипида в эллинистическом и римском образовании. Пер. B.К. Пичугиной // Hypothekai. №2, 2018. C. 231-251.

Можайский (2007) - Можайский А.Ю. Внешнеполитический курс Фиванского полиса в классический период. Дис. ... канд. ист. наук. М., 2007.

Можайский (2018) - Можайский А.Ю. Реки и ворота Фив в трагедиях Эсхила, Софокла и Еврипида как часть образовательного пространства города // Нурothekai. №2, 2018. C. 79-96.

Пичугина, Можайский (2020) - Пичугина В.К., Можайский А.Ю. Трагическая визуализация образовательного пространства Фив в «Фиваиде» Стация // ПРА ЕНМА. Проблемы визуальной семиотики

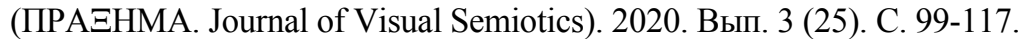

\section{REFERENCES}

All citations in this article are reproduced according to the electronic database of classical texts "The Perseus Digital Library".

Alcock (1997) - Alcock S.E. The Heroic Past in a Hellenistic Present // Hellenistic Constructs. Essays in Culture, History and Historiography / Eds. P. Cartledge, P. Garnsey, E. Gruen. Berkeley Los Angeles, and London: University of California Press, 1997.

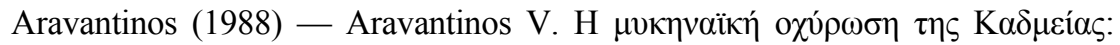

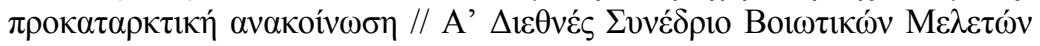

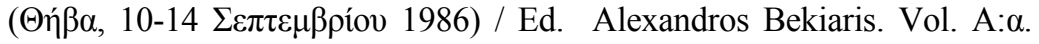
Athens, 1988. P. 113-136.

Aravantinos (2014) - Aravantinos V. The Inscriptions from the Sanctuary of Herakles at Thebes: An Overview // The Epigraphy and History of Boeotia: New Finds, New Prospects = Brill Studies in Greek and Roman Epigraphy Volume 4 / Ed. N. Papazarkadas. Leiden \& Boston: Brill, 2014. P. 149-210.

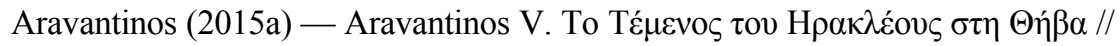

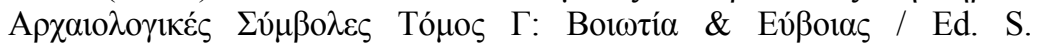
Oikonomou. Athens: Museum of Cycladic Art, 2015. P. 85-106.

Aravantinos (2015b) - Aravantinos V. The Palatial Administration of Thebes Updated // Tradition and Innovation in the Mycenaean Palatial Polities (Mykenische Studien 34) / Eds. F. Ruppenstein, J. Weilhartner. Vienna: Österreichische Akadamie der Wissenschaften, 2015. P. 19-49. 
Aravantinos (2017) - Aravantinos V. The sanctuaries of Herakles and Apollo Ismenios at Thebes: new evidence // Interpreting the Seventh Century BC. Tradition and Innovation / Eds. X. Charalambidou and C. Morgan. Oxford: Archaeopress Publishing Ltd., 2017. P. 218-227.

Aravantinos et al. (2018) - Aravantinos V.L., Fappas I., Angelidis P., Louka M., Sepetzoglou N. The Female Figure in the Pictorial Tradition of Mycenaean

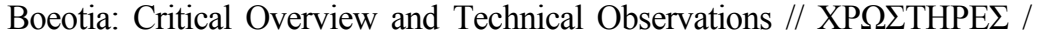
PAINTBRUSHES. Wall-painting and Vase-painting of the Second Millennium BC in Dialogue. Proceedings of the International Conference on Aegean Iconography Held at Akrotiri, Thera, 24-26 May 2013, University of Ioannina / Hellenic Ministry of Culture and Sports - Archaeological Receipts Fund / Ed. A. Vlachopoulos. Athens, 2018. P. 427-449.

Berman (2015) - Berman D.W. Myth, Literature, and the Creation of the Topography of Thebes. Cambridge: Cambridge University Press, 2015.

Bintliff (1994) - Bintliff J.L. Territorial behaviour and the natural history of the Greek polis // Stuttgarter Kolloquium zur Historischen Geographie des Altertums, 4 / Eds. E. Olshausen, H. Sonnabend. Amsterdam: Hakkert Verlag, 1994. P. 207 - 249.

Bintliff (1999) - Bintliff J.L. Pattern and process in the city landscapes of Boeotia, from Geometric to Late Roman times // Territoire des Cités Grecques (BCH Supplement) / Ed. M. Brunet. Athene: Ecole Française d'Athénes, 1999. P. 15-33.

Buck (1979) — Buck R.J. A History of Boeotia. Edmonton: The University of Alberta Press, 1979.

Buck (1994) — Buck R.J. Boiotia and the Boiotian League, 423-371 B.C. Edmonton: The University of Alberta Press, 1994.

Calza et al. (1977) - Antichità di Villa Doria Pamphilj / Eds. Calza R., Bonanno Aravantinos M., Messineo G., Palma B., Pensabene P. Rome: De Luca, 1977.

Casson (1974) - Casson L. Travel in the Ancient World. London: George Allen and Unwin, 1974.

Champion-Smith (1998) - Champion-Smith V.A. Pausanias in Athens: An Archaeological Commentary on the Agora of Athens. PhD thesis, University College London, 1998.

Cribiore (2001) - Cribiore R. The grammarian's choice: the popularity of Euripides' Phoenissae in Hellenistic and Roman education // Education in Greek and Roman antiquity / Ed. Y.L. Too. Leiden; Boston; Koln: Brill, 2001. P. 241-259. 
Cribiore (2018) — Cribiore R. Vybor grammatika: populyarnost' «Finikiyanok» Evripida v ellinisticheskom i rimskom obrazovanii. Per. V.K. Pichuginoj // Hypothekai. №2, 2018. S. 231-251.

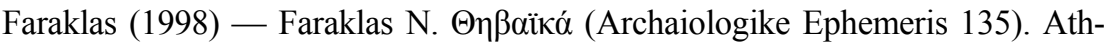
ens, 1998.

Farnell (1921) - Farnell L.R. Greek Hero Cults and Ideas of Immortality. Oxford: Oxford University Press, 1921.

Fossey (1988) - Fossey J.M. Topography and Population of Ancient Boiotia. Chicago: Ares Publishers Inc., 1988.

Frazer (1898) - Pausanias's Description of Greece, translated with a commentary by J.G. Frazer. In six volumes. London: Macmillan and Co., 1898.

Henderson (1923) - Henderson B.W. The Life and Principate of the Emperor Hadrian. London: Methuen, 1923.

Johnson (1931) — Johnson F. Corinth IX, Sculpture 1896-1923. Cambridge, Mass.: Harvard University Press, 1931.

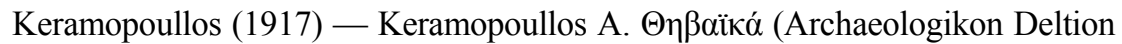
3). Athens, 1917.

Körte (1890) - Körte G. I rilievi delle urne etrusche (Band 2,1). Berlin, 1890.

Krauskopf (1990) — Krauskopf I. Kapaneus // LIMC V. 1990. P. 952-963.

Krauskopf (1994) — Krauskopf I. Septem // LIMC VII. 1994. P. 730-748.

Lamari (2017) - Lamari A.A. Phoenician Women // A Companion to Euripides, First Edition / Ed. Laura K. McClure. Chichester, West Sussex: John Wiley \& Sons Inc., 2017. P. 258-269.

Lamont (2019) — Lamont J.L. The Phenomenon of Incubation in Antiquity // The Classical Review. Vol. 69, Iss. 1, 2019. P. 178-181.

Landskron (2015) - Landskron A. Das Heroon von Trysa. Ein Denkmal in Lykien zwischen Ost und West (Schriften des Kunsthistorischen Museums 13 A), Textband. Wien: Verlag Holzhausen GmbH, 2015.

Middleton (1892) - Middleton J.H. The Lewis collection of gems and rings in the possession of Corpus Christi College, Cambridge, with an introductory essay on ancient gems. London: C.J. Clay \& Sons, Cambridge University Press Warehouse, 1892.

Moggi, Osanna (2010) - Moggi M., Osanna M. Pausania. Guida della Grecia. Libro IX. Milano: Fondazione Lorenzo Valla - Arnoldo Mondadori, 2010 . 
Mozhajsky (2007) - Mozhajsky A. Yu. Vneshnepoliticheskij kurs Fivanskogo polisa $\mathrm{v}$ klassicheskij period. Dis. ... kand. ist. nauk. M., 2007.

Mozhajsky (2014) - Mozhajsky A. Yu. The Archaic Wall of Greater Thebes: Chronological and Topographical Problems // Graeco-Latina Brunensia 19, 2014, 2. P. 71-79.

Mozhajsky (2018) - Mozhajsky A. Yu. Reki i vorota Fiv v tragediyah Eskhila, Sofokla i Evripida kak chast' obrazovatel'nogo prostranstva goroda // Hypothekai. №2, 2018. S. 79-96.

Musti (1988) - Musti D. La struttura del libro di Pausania sulla Beozia // A'

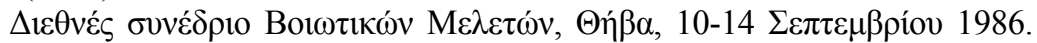
Athens. Vol. I., 1988. P. 333-345.

Osborne (2009) - Osborne R. Greece in the Making, 1200-479 BC. Second edition. London and New York: Routledge, 2009.

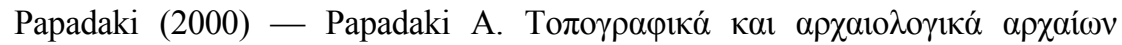

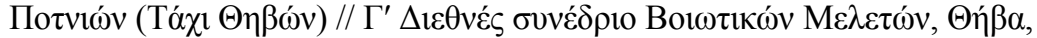
4-8 $\Sigma \varepsilon \pi \tau \varepsilon \mu \beta$ píov 1996. Athens. Vol. I., 2000. P. 357-369.

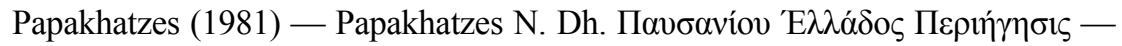

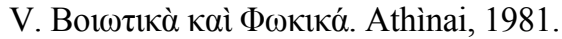

Petropoulou (1981) - Petropoulou A. The Eparche documents and the early oracle at Oropus // GRBS 22, 1981. P. 39-63.

Pichugina, Mozhajsky (2020) - Pichugina V.K., Mozhajsky A. Yu. Tragic visualization of the educational space of Thebes in Statius' Thebaid // ПРАЕНMA 3 (25), 2020. P. 99-117.

Regenbogen (1956) - Regenbogen O. Pausanias // Realencyclopädie der classischen Altertumswissenschaft. Supplement 8. Edited by August Pauly. Stuttgart: J. B. Metzler, 1956. S. 1008-1097.

Renberg (2017) - Renberg G. H. Where Dreams May Come. Incubation Sanctuaries in the Greco-Roman World. In two volumes. (Religions in the Graeco-Roman World 184.). Leiden and Boston: Brill, 2017.

Robert (1890) — Robert C. Die antiken Sarkophag-Reliefs II: Mythologische Cyklen. Berlin: G. GROTE'sche verlagsbuchhandlung, 1890.

Schachter (1981) - Schachter A. The Cults of Boiotia 1, BICS Suppl. 38.1. London: Institute of Classical Studies, 1981.

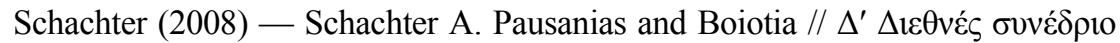

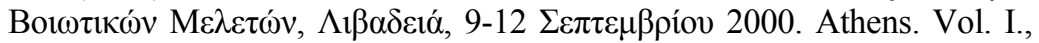
2008. P. 649-664. 
Schachter (2016) - Schachter A. Boiotia in Antiquity: Selected Papers. Cambridge: Cambridge University Press, 2016.

Sélincourt (2001) — Sélincourt A. de. The World of Herodotos. London: Phoenix Press, 2001.

Sichtermann, Koch (1975) - Sichtermann H, Koch G. Griechische Mythen auf römischen Sarkophagen. Tübingen: Ernst Wasmuth, 1975.

Simon (2013) - Simon E. Greek Myth in Etruscan Culture // The Etruscan World / Ed. J.M. Turfa. London and New York: Routledge, 2013. P. 495512.

Symeonoglou (1985). - Symeonoglou S. The Topography of Thebes from the Bronze Age to Modern Times. Princeton: Princeton University Press, 1985.

Tarn (1910) - Tarn W.W. The dedication Ship of Antigonos Gonatas // The Journal of Hellenic Studies, 30 ( 2), 1910. P. 209-222.

van Wijk (2019) — van Wijk R. A Bittersweet Rivalry. The interstate relations between Athens and Boiotia during the Archaic and Classical Period (550323 B.C.E.). Dissertation zur Erlangerung der Doktorwürde an der Philosophischen Fakultät der Universität Freiburg (CH). Pays-Bas, 2019.

Wallace (1979) — Wallace P. Strabo's Description of Boiotia: a Commentary (Strabo). Heidelberg: Winter, 1979.

Wilamowitz-Möellendorff (1883) — Wilamowitz-Möellendorff U. Die Beiden Elektren // Hermes, 18. Bd., H. 2, 1883. P. 214-263.

Wycherley (1982) - Wycherley R.E. Pausanias and Praxiteles // Hesperia Supplement: 20, 1982. P. 182-191.

Young (1922) - Young J.D. A Sarcophagus at Corinth // American Journal of Archaeology, Vol. 26, No. 4, 1922. P. 430-444. 